\title{
Efficacy of balance training for hip fracture patients: a meta-analysis of randomized controlled trials
}

\author{
Jia-qi $\mathrm{Wu}^{1}$, Lin-bo Mao ${ }^{1}$ and Jian $\mathrm{Wu}^{2^{*}}$
}

\begin{abstract}
Background: To investigate whether the clinical effects of balance training were improved in hip fracture patients. Methods: Electronic databases which included PubMed, Embase, Web of Science, and the Cochrane Library up to December 2018 were searched. High-quality randomized controlled trials (RCTs) and prospective clinical controlled studies were selected based on inclusion criteria. Stata 12.0 was used for the meta-analysis. Standard mean difference (SMD) with 95\% confidence interval (Cl) was used to assess the effects.

Results: Finally, 9 studies with 872 patients (balance training $=445$, control $=427$ ) were included in our meta-analysis (published between 1997 and 2018). Compared with the control group, balance training group showed a significant increase in overall function (SMD $=0.59,95 \% \mathrm{Cl}[0.25,0.93], P=0.001)$, gait speed (SMD $=0.63,95 \% \mathrm{Cl}[0.19,1.07]$, $P=0.005)$, lower limb strength $(\mathrm{SMD}=0.73,95 \% \mathrm{Cl}[0.50,0.95], P=0.000)$, activities of daily living (ADLs) $(\mathrm{SMD}=0.97$, $95 \% \mathrm{Cl}[0.61,1.34], P=0.000)$, performance task scores (SMD $=0.41,95 \% \mathrm{Cl}[0.21,0.61], P=0.000)$, and health-related quality of life (HRQoL) scores (SMD $=0.32,95 \% \mathrm{Cl}[0.16,0.47], P=0.000)$.

Conclusions: Our meta-analysis revealed that the balance training group has improved overall physical functioning, gait, lower limb strength, performance task, and activity of daily living than the control group. More high-quality and large-scale RCTs are needed to identify the optimal regimen of balance training after hip fracture.
\end{abstract}

Keywords: Osteonecrosis of femoral head, Core decompression, Autologous bone, Marrow cells implantation, Meta-analysis

\section{Background}

Hip fractures are a common problem among older adults and can have a devastating impact on the ability of older patients to remain independent $[1,2]$. However, individuals following hip fractures experience greater postural sway, possibly due to reduced muscular strength and proprioception [3]. Such physical limitations could hinder daily living and increase the risks of falls in patients following hip fracture compared to their healthy, age-matched counterparts [4].

Report has shown that 2 years after a hip fracture, more than half of men and 39\% of women are dead or living in a long-term care facility [5]. In addition, balance

\footnotetext{
* Correspondence: 1259505194@qq.com

2Institute Office, Jingjiang People's Hospital, No. 28, Zhongzhou road,

Jingjiang, Taizhou 214500, Jiangsu Province, China

Full list of author information is available at the end of the article
}

deficit was the major risk factor for falls [6]. There is a need to identify optimal strategies to improve functional outcomes for hip fracture patients [7].

Evidence suggests that rehabilitation plays a role in guaranteeing recovery and enhancing quality of life following hip fracture [8]. And balance training could prevent falls in elderly individuals [9]. However, the effects of balance training for clinical outcomes in hip fracture patients were unknown. Therefore, it is necessary to conduct a meta-analysis comparing balance training for hip fracture patients.

Thus, we undertook a meta-analysis to evaluate whether balance training is superior to placebo with respect to (1) overall function, (2) gait speed, (3) lower limb strength, (4) activities of daily living (ADLs), (5) performance task scores, and (6) health-related quality of life (HRQoL). We hypothesized that balance training 
in the balance training group results in more hip function and higher limb strength than in the control group.

\section{Materials and methods}

The current meta-analysis was performed according to the recommendations of the Cochrane Handbook for Systematic Reviews of Interventions and was reported in compliance with the Preferred Reporting Items for Systematic Reviews and Meta-Analyses (PRISMA) statement guidelines [10].

\section{Search strategy}

Two reviewers performed an electronic literature search for randomized controlled trials (RCTs) or prospective clinical controlled studies comparing the balance training with control in the management of hip fracture. The electronic databases include PubMed, Embase, Web of Science, and the Cochrane Library up to December 2018. No language or date restrictions were applied. The following terms were used as keywords: $((()((($ Fractures, Subtrochanteric) OR Subtrochanteric Fractures) OR Fractures, Intertrochanteric) OR Intertrochanteric
Fractures) OR Fractures, Trochanteric) OR Trochanteric Fractures) OR Fractures, Hip)) AND (((((Training, Circuit) OR Circuit Training) OR Exercises, Circuit-Based) OR Exercise, Circuit-Based) OR balance training). In addition, further articles were obtained by reviewing references of the selected articles. The detail retrieval process is shown in Fig. 1.

\section{Inclusion criteria}

Randomized controlled trials were included if they met the PICOS criteria as follows: Population: patients with hip fracture; Intervention: balance training; Comparator: placebo; Outcomes: overall function, gait speed, lower limb strength, ADLs, performance task scores, and HRQoL; Study design: RCTs or prospective clinical controlled studies.

\section{Data extraction}

Two reviewers independently retrieved the relevant data from articles using a standard data extraction form. The extracted data included publication date, authors, study design, inclusion and exclusion criteria, number and

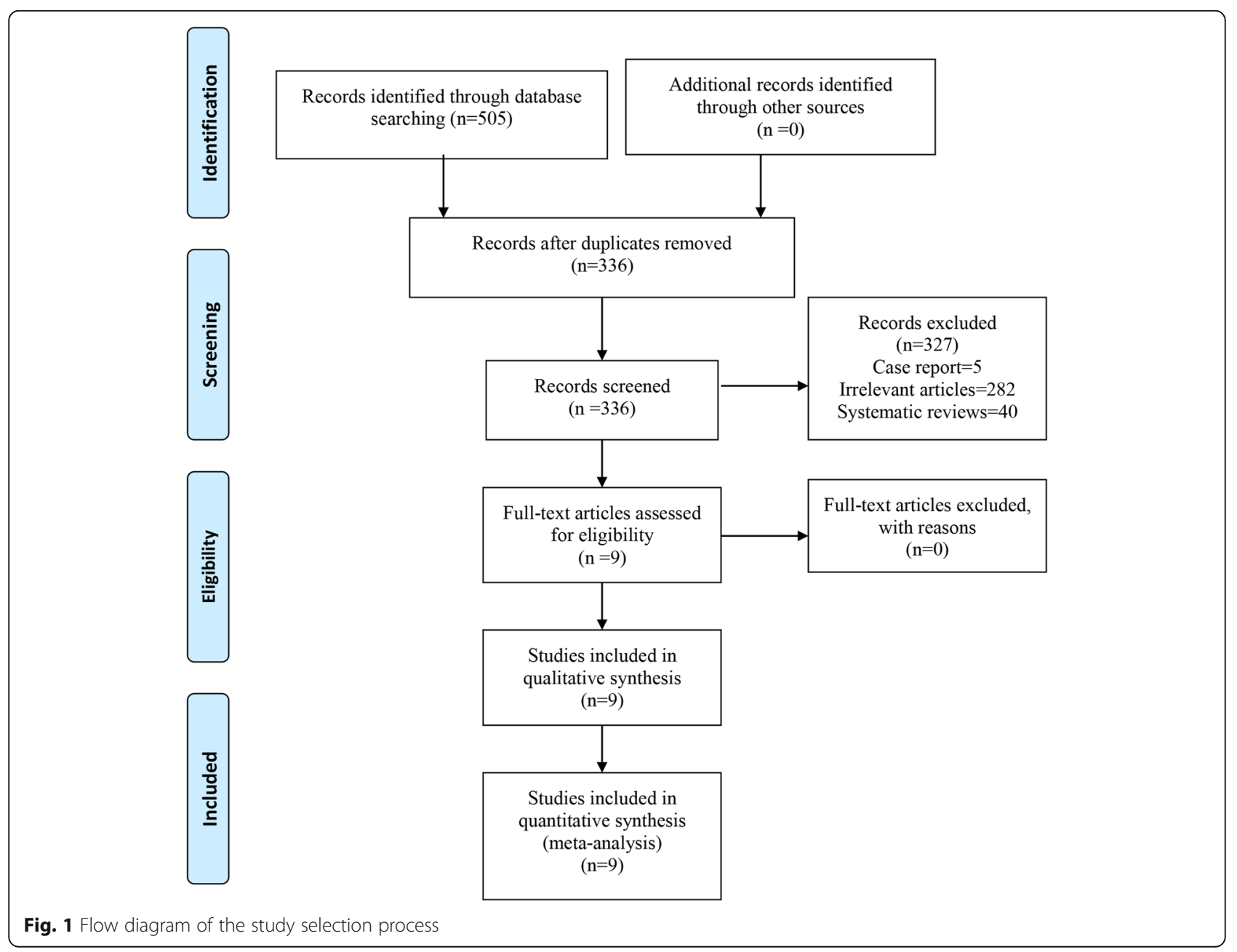


demographics of participants, number of included hips, surgical procedure, duration of follow-up, and outcomes. For missing data, such as standard deviations, we tried to get it by contacting the original author first. If it did not work, we calculated missing standard deviations from other available data such as standard errors or the formulas in the Cochrane Handbook for Systematic Reviews of Interventions. Two reviewers extracted the data independently, and any disagreement was discussed until a consensus was reached.

\section{Risk of bias and quality assessment}

The methodological bias and quality of included studies were assessed by The Cochrane Collaboration's tool for assessing the risk of bias according to the Cochrane Handbook for Systematic Reviews of Interventions [11]. It is a two-part tool with seven specific domains: sequence generation, allocation concealment, blinding of participants and personnel, blinding of outcome assessment, incomplete outcome data, selective outcome reporting, and other sources of bias.

\section{Statistical and subgroup analysis}

Stata 12.0 (Stata Corp., College Station, TX) was used to perform the meta-analysis. We used standard difference (SMD) and 95\% confidence interval (CI) to assess continuous variable outcomes. For dichotomous outcomes, relative risks (RR) with a $95 \% \mathrm{CI}$ were presented. Heterogeneity between studies was assessed by $I^{2}$ and $\chi^{2}$ test. When $I^{2}<50 \%$ and $P>0.1$, we used a fixed-effects model to evaluate; otherwise, a random-effects was used. In addition, subgroup analysis was performed to explore the source of heterogeneity when heterogeneity existed.

\section{Results}

\section{Search results}

The flowchart for the inclusion of articles is shown in Fig. 1. Initially, a total of 505 studies were searched via the databases and other sources (e.g., references). And 169 of the 505 studies were excluded due to the duplicates by Endnote Software (Version X7, Thompson Reuters, CA, USA). After reading the title and abstract, 327 trials were excluded according to the inclusion criteria. Finally, 9 studies [12-20] with 872 patients (balance training $=445$, control $=427$ ) were included in our meta-analysis (published between 1997 and 2018).

\section{General characteristic of the included studies}

Table 1 shows the detailed characteristics of the trials included. Three studies were originated from the USA, three were from Australia, one from Germany, one from Italy and one from China. Sample size of the included

Table 1 General characteristic of the included RCTs

\begin{tabular}{|c|c|c|c|c|c|c|c|c|}
\hline Author & Region & $\begin{array}{l}\text { No. of } \\
\text { patients }(n)\end{array}$ & Type of exercise & Control & $\begin{array}{l}\text { Duration } \\
\text { and frequency }\end{array}$ & Follow-up & Outcomes & Study \\
\hline Binder 2004 & USA & $46 / 44$ & $\begin{array}{l}\text { Phase 1: flexibility, } \\
\text { balance, coordination, } \\
\text { movement speed; } \\
\text { phase } 2 \text { : add progressive } \\
\text { resistance training }\end{array}$ & $\begin{array}{l}\text { Core exercise } \\
\text { focused on } \\
\text { flexibility }\end{array}$ & $\begin{array}{l}6 \text { months } \\
\text { ( } 3 \text { days a week) }\end{array}$ & 6 months & $3,5,6$ & $\mathrm{RCT}$ \\
\hline Hauer 2002 & Germany & $15 / 13$ & $\begin{array}{l}\text { Progressive functional } \\
\text { training with walking, } \\
\text { stepping, or balancing }\end{array}$ & $\begin{array}{l}\text { Motor placebo } \\
\text { activities } \\
\text { (calisthenics games) }\end{array}$ & $\begin{array}{l}3 \text { months } \\
\text { ( } 3 \text { days a week) }\end{array}$ & 3 months & $1,2,3,6,7$ & $\mathrm{RCT}$ \\
\hline Latham 2014 & USA & $120 / 112$ & $\begin{array}{l}\text { Standing from a chair, } \\
\text { climbing a step }\end{array}$ & Nutritional education & $\begin{array}{l}6 \text { months } \\
\text { ( } 3 \text { days a week) }\end{array}$ & 9 months & $1,2,4,5,7$ & $\mathrm{RCT}$ \\
\hline Monticone 2018 & Italy & $26 / 26$ & $\begin{array}{l}\text { Balance task-specific } \\
\text { training while standing }\end{array}$ & $\begin{array}{l}\text { Walking training and } \\
\text { open kinetic chain exercise }\end{array}$ & $\begin{array}{l}3 \text { weeks } \\
\text { ( } 3 \text { days a week) }\end{array}$ & $\begin{array}{l}12 \\
\text { months }\end{array}$ & $1,2,3,4,7$ & $\mathrm{RCT}$ \\
\hline Moseley 2009 & Australia & $80 / 80$ & $\begin{array}{l}\text { [Inpatient] Standing up, } \\
\text { sitting down, tapping the } \\
\text { foot, and stepping onto } \\
\text { and off a block }\end{array}$ & $\begin{array}{l}\text { Lower dose exercise } \\
\text { (30 min/day) }\end{array}$ & $\begin{array}{l}4 \text { months } \\
\text { ( } 14 \text { days a week) }\end{array}$ & 4 months & $3,4,5$ & $\mathrm{RCT}$ \\
\hline Peterson 2004 & USA & $38 / 32$ & $\begin{array}{l}\text { With balance and gait } \\
\text { training }\end{array}$ & $\begin{array}{l}\text { Conventional physical } \\
\text { therapy }\end{array}$ & $\begin{array}{l}2 \text { months } \\
\text { ( } 2 \text { days a week) }\end{array}$ & $\begin{array}{l}12 \\
\text { months }\end{array}$ & $1,2,4,6,7$ & $\mathrm{RCT}$ \\
\hline Sherrington 1997 & Australia & $20 / 20$ & $\begin{array}{l}\text { Stepping exercise with } \\
\text { weight-bearing exercise }\end{array}$ & No treatment & $\begin{array}{l}1 \text { month } \\
\text { (7 days a week) }\end{array}$ & 1 month & $1,2,4,5,7$ & $\mathrm{RCT}$ \\
\hline Sherrington 2004 & Australia & $40 / 40$ & $\begin{array}{l}\text { Sit-to-stand, lateral } \\
\text { step-up, forward } \\
\text { step-out-and-over, } \\
\text { forward foot taps }\end{array}$ & $\begin{array}{l}\text { Non-weight bearing } \\
\text { exercise }\end{array}$ & 4 months (NS) & 4 months & $1,2,3,6,7$ & $\mathrm{RCT}$ \\
\hline Zheng 2010 & China & $60 / 60$ & $\begin{array}{l}\text { With balance and gait } \\
\text { training }\end{array}$ & No treatment & $\begin{array}{l}6 \text { months } \\
\text { ( } 3 \text { days a week) }\end{array}$ & 6 months & & $\mathrm{RCT}$ \\
\hline
\end{tabular}




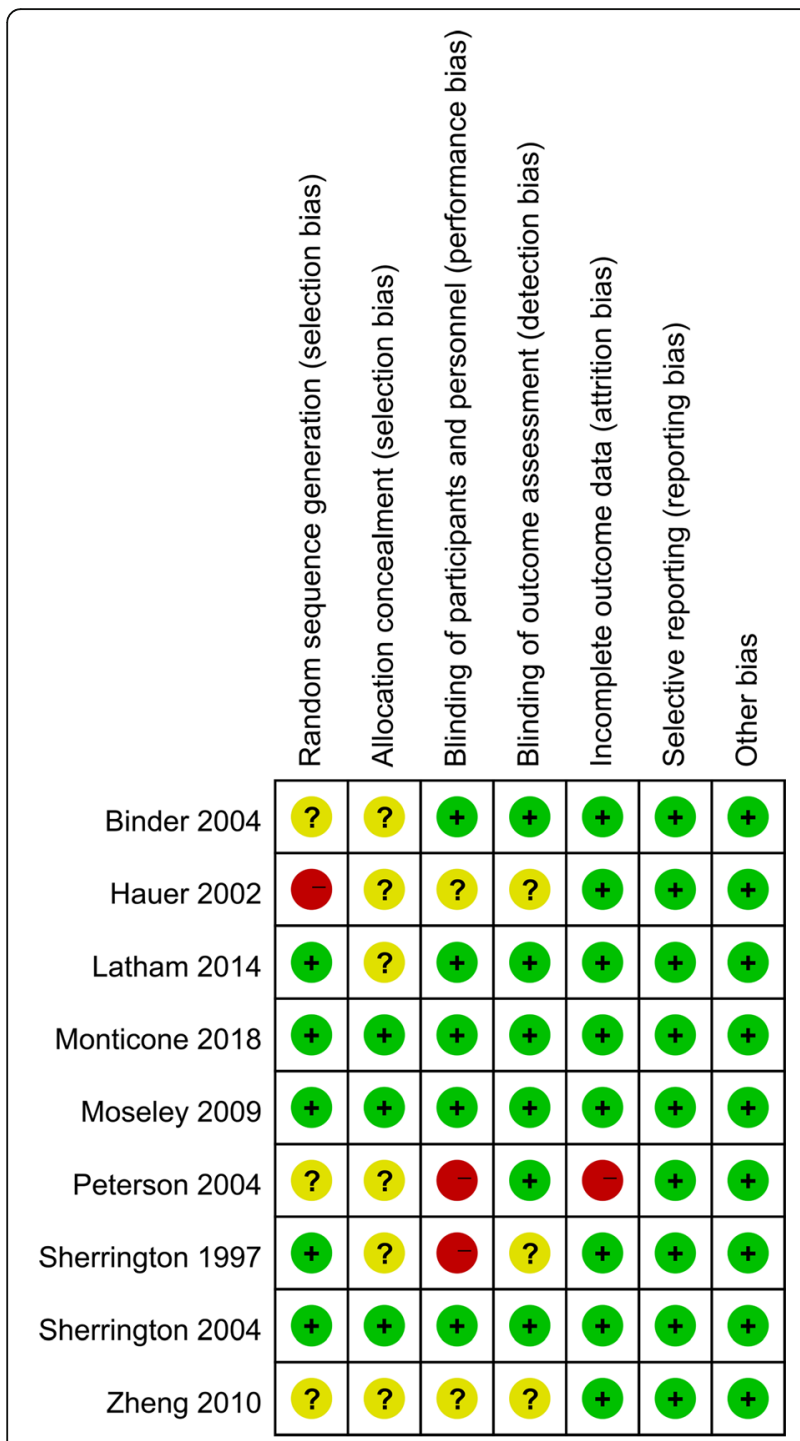

Fig. 2 Risk of bias summary studies ranged from 13 to 120 . The type of balance training is different from each other. Duration ranged from 3 weeks to 6 months. Follow-up duration ranged from 1 to 12 months.

\section{Risk of bias in included studies}

Risk of bias summary and risk of bias graph are shown in Fig. 2 and Fig. 3 respectively. A total of three studies were rated as low risk of bias, three studies were qualified as high risk of bias, and the rest of the studies were rated as unclear risk of bias.

\section{Results of meta-analysis \\ Overall function}

Nine studies enrolling 872 patients reported overall function postoperatively. There was a high heterogeneity existed between the nine studies $\left(I^{2}=81.9 \%\right.$; $P=$ 0.000 , Fig. 4). Thus, a random-effects model was performed. And there was a significant difference between the two groups (SMD $=0.59,95 \%$ CI $[0.25,0.93]$, $P=0.001$; Fig. 4).

\section{Gait speed}

Gait speed was reported in six studies enrolling 682 patients. Large heterogeneity existed between the six studies $\left(I^{2}=85.7 \% ; P=0.000\right.$, Fig. 5$)$. So we adopted a random-effects model, and significant difference existed in the two groups ( $\mathrm{SMD}=0.63,95 \%$ CI $[0.19$, 1.07], $P=0.005$; Fig. 5).

\section{Lower limb strength}

Seven studies including 762 patients reported lower limb strength. Heterogeneity existed between the five studies $\left(I^{2}=51.7 \% ; P=0.053\right.$, Fig. 6). Thus, a random-effects model was performed. And meta-analysis showed balance training in the balance training group has a beneficial role in increasing lower limb strength than in the control group (SMD $=0.73,95 \%$ CI $[0.50,0.95], P=0.000$; Fig. 6).

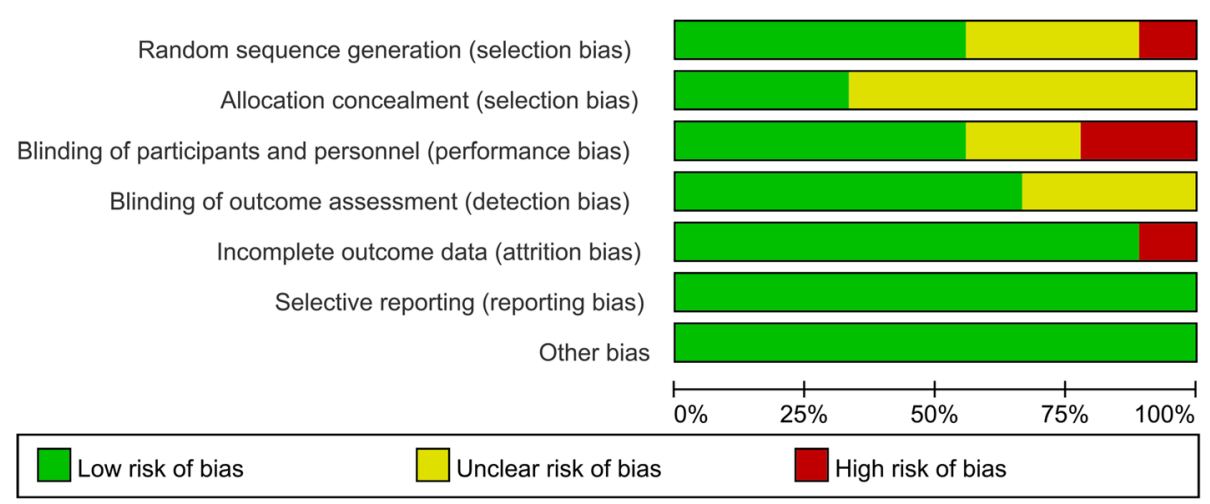

Fig. 3 Risk of bias graph 


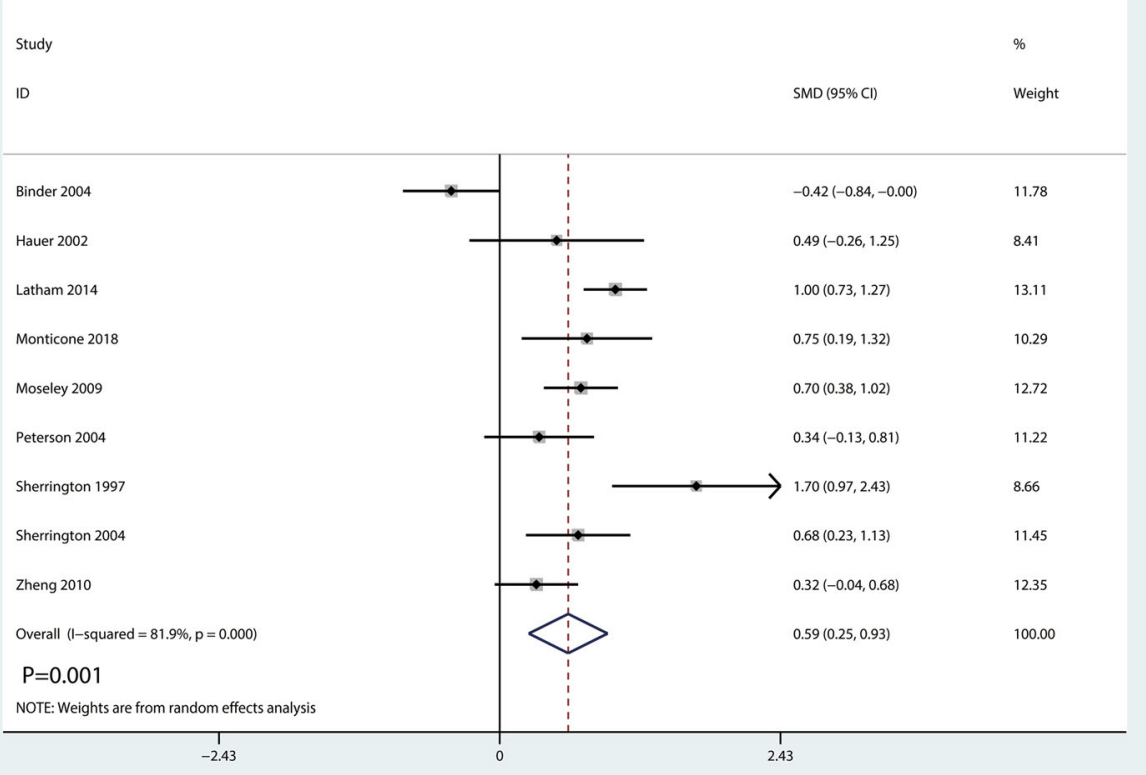

Fig. 4 Forest plot for the comparison of overall function between the balance training group and control group

\section{ADLs}

Six studies including 662 patients reported the ADLs postoperatively. There was a high heterogeneity between the two studies $\left(I^{2}=77.0 \% ; P=0.001\right.$, Fig. 7). A random-effects model was conducted. And meta-analysis showed balance training in the balance training group has a beneficial role in increasing ADLs than in the control group (SMD $=0.97,95 \%$ CI $[0.61,1.34], P$ $=0.000$; Fig. 7).

\section{Performance task scores}

Nine studies including 872 patients reported performance task scores postoperatively. Mild heterogeneity existed between the three studies $\left(I^{2}=\right.$ $48.1 \%, P=0.051$, Fig. 8). So we conducted a random-effects model. Meta-analysis revealed that balance training could significantly increase the performance task scores $(\mathrm{SMD}=0.41,95 \%$ CI $[0.21$, 0.61 ], $P=0.000$; Fig. 8 ).

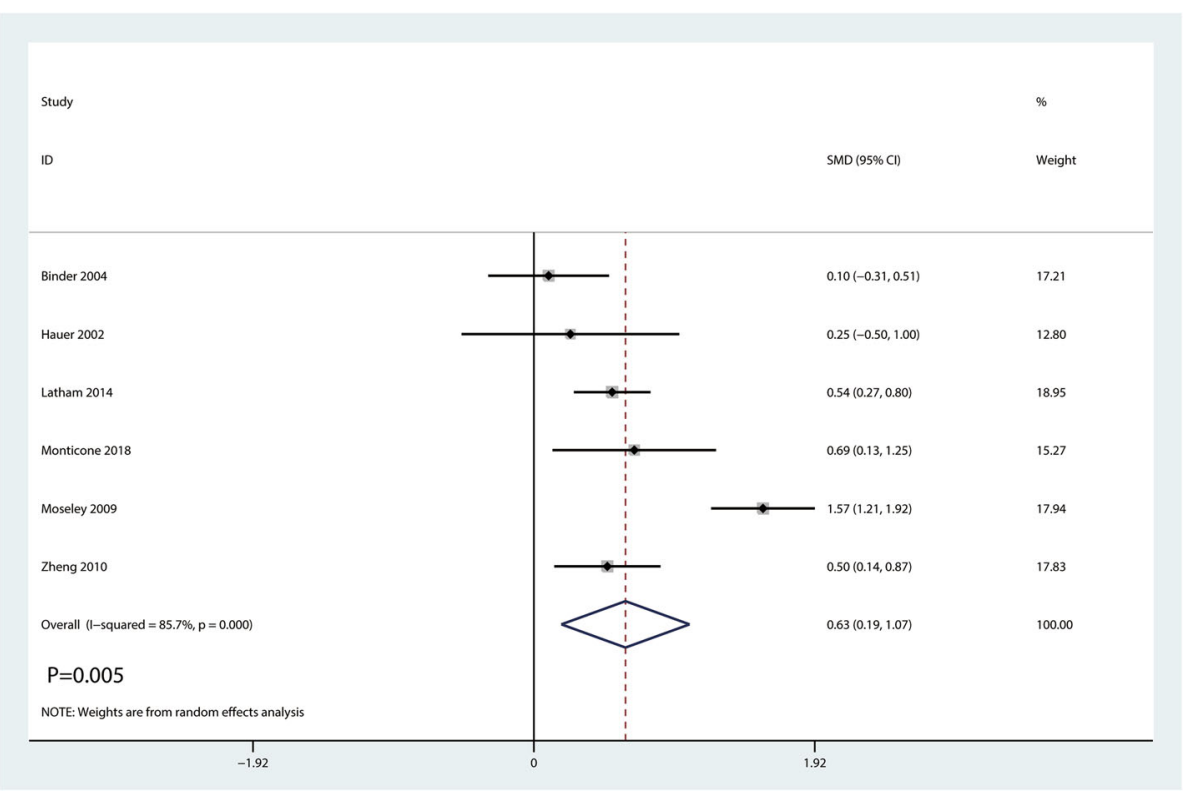

Fig. 5 Forest plot for the comparison of gait speed between the balance training group and control group 


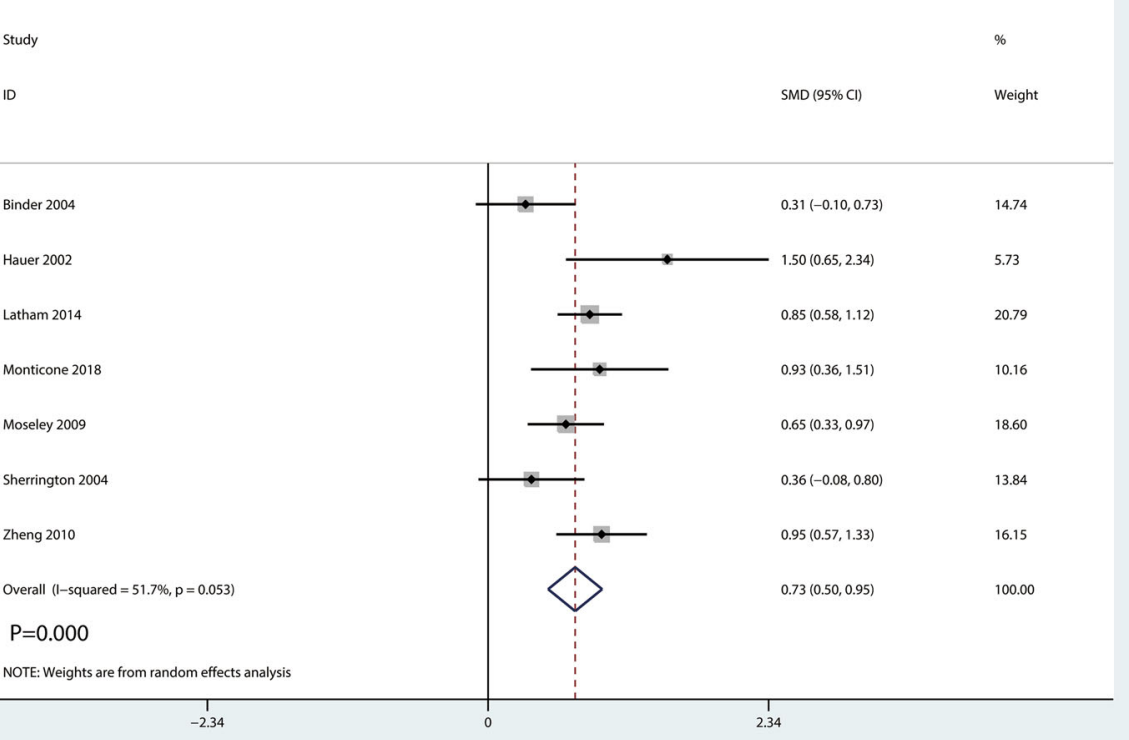

Fig. 6 Forest plot for the lower limb strength between the balance training group and control group

\section{HRQoL scores}

Seven studies including 642 patients reported HRQoL scores postoperatively. No heterogeneity existed between the seven studies $\left(I^{2}=0.0 \%, P=0.954\right.$; Fig. 9). So we conducted a random-effects model. And meta-analysis showed significant difference between the two groups $(\mathrm{SMD}=0.32$, 95\% CI [0.16, 0.47], $P=0.000$; Fig. 9).
Publication bias, sensitivity analysis, and subgroup analysis For the meta-analysis of balance training on overall function, there was no evidence of publication bias by inspection of the funnel plot (Fig. 10) and formal statistical tests (Egger test, $P=0.69$, Fig. 11 ; Begg test, $P=$ 0.73 , Fig. 12). Sensitivity analysis was performed by omitting included studies in turn, and results found that

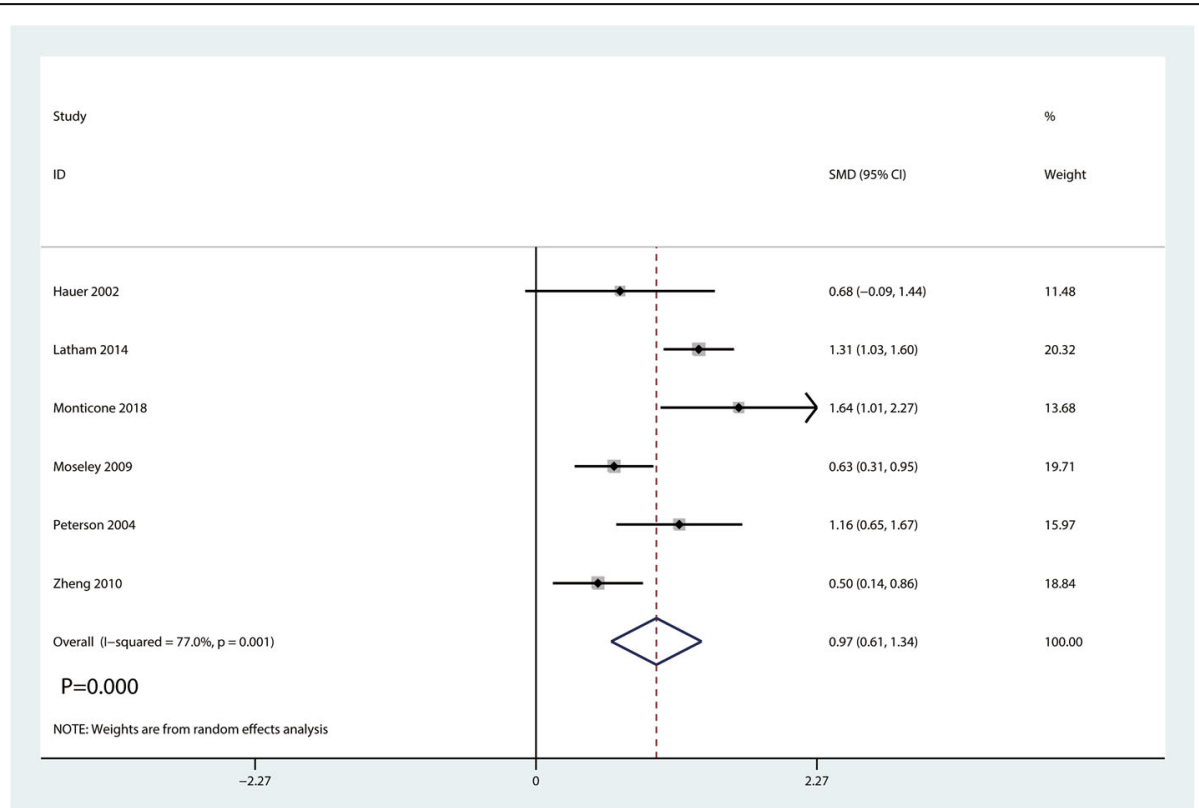

Fig. 7 Forest plot for the comparison of ADLs between the balance training group and control group 


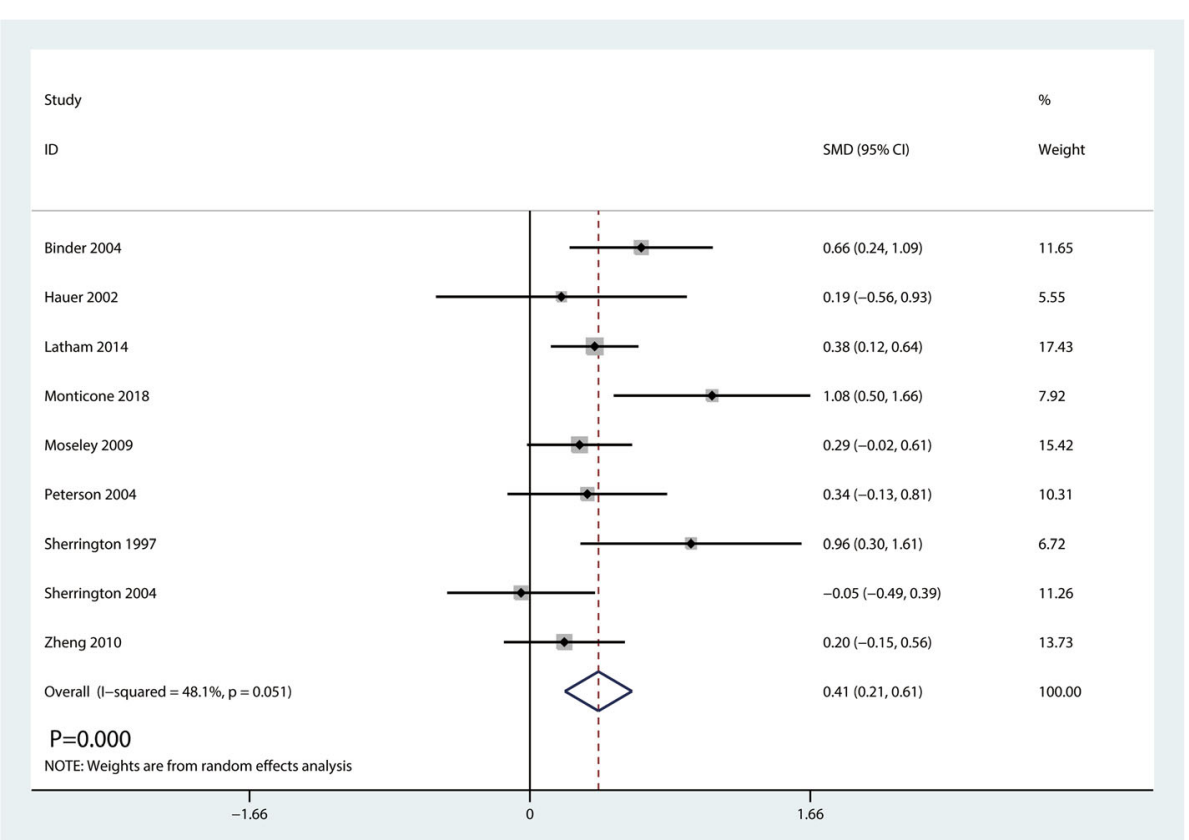

Fig. 8 Forest plot for the comparison of performance task scores between the balance training group and control group

after removing each studies in turn, overall effect size was not changed (Fig. 13).

Subgroup analysis results are shown in Table 2. The findings of increased overall function were consistent in all subgroup analyses except for the frequency training and unclear/high risk of bias subgroups. Results found that high-frequency training is superior than low-frequency training in increasing overall function.

\section{Discussion}

\section{Main findings}

Results of this meta-analysis revealed that balance training has a positive role in increasing overall function for hip fracture patients. Moreover, balance training in the balance training group could significantly increase gait, lower limb strength, ADLs, performance task scores, and HRQoL scores than in the control group. Subgroup

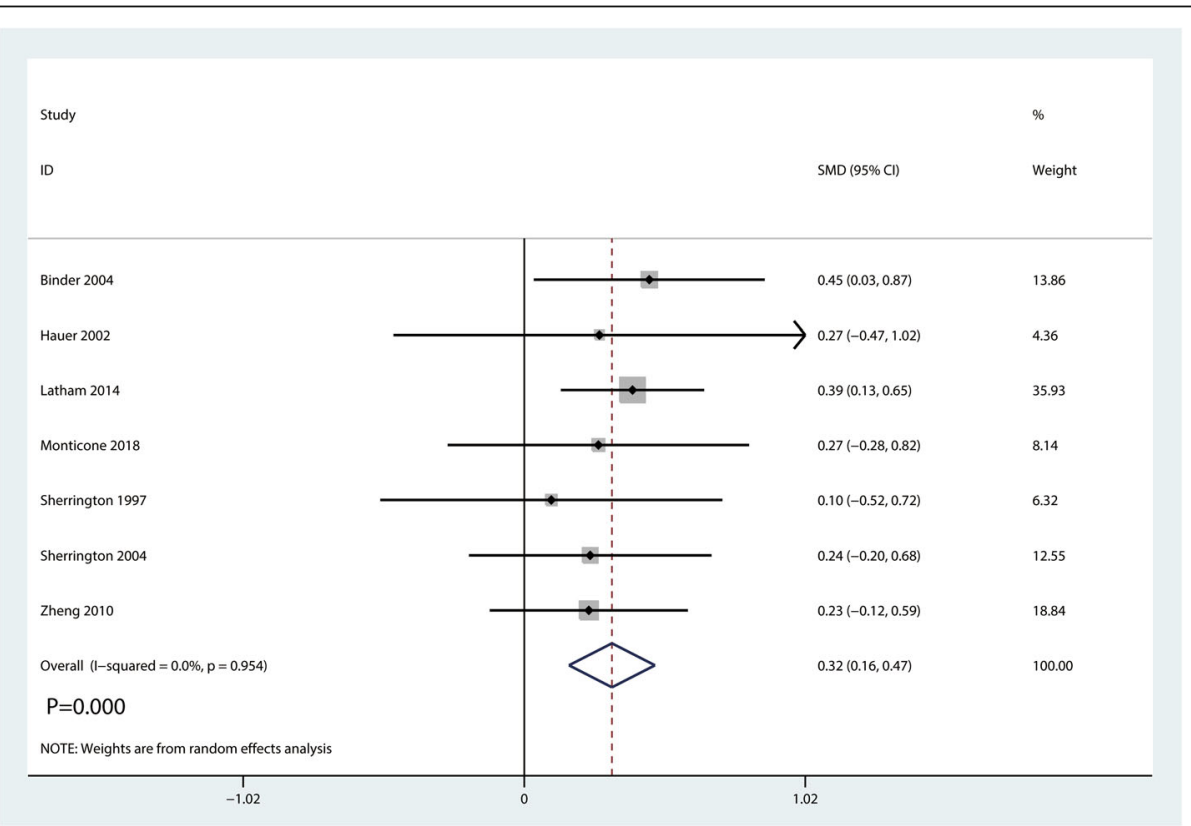

Fig. 9 Forest plot for the comparison of HRQoL scores between the balance training group and control group 


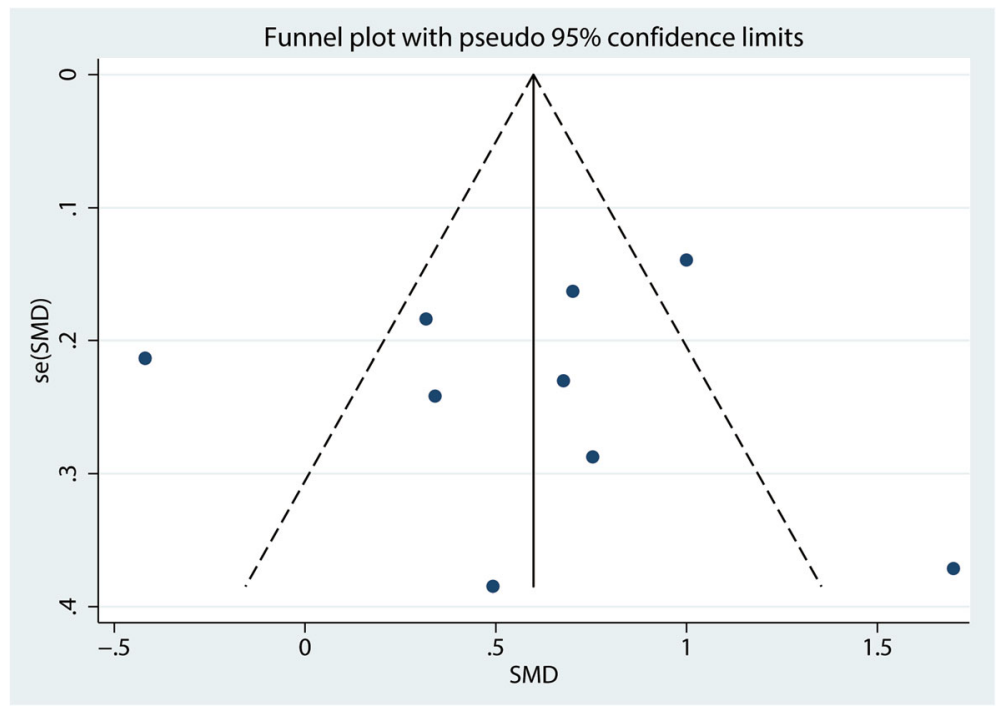

Fig. 10 Funnel plot of the overall function between balance the training group and control group

results have shown that high-frequency training was superior than low-frequency training for increasing overall function.

\section{Comparison with other meta-analyses}

Only one relevant meta-analysis on the topic has been published [21]. Differences between ours and the previous ones should be noted. Different training frequency should be separately analyzed. Current meta-analysis performed publication bias, subgroup analysis, and subgroup analysis for overall function. Doma et al. [22] indicated that balance training improved walking capacity, balance-specific performance, and functional outcome measures for elderly individuals following total knee arthroplasty.

\section{Implications for clinical practice}

Our meta-analysis showed that balance training could significantly increase overall function and lower limb strength after hip fracture. Moreover, high-frequency training was recommended. Latham et al. [14] revealed that the use of a home-based functionally oriented exercise program resulted in modest improvement in physical function at 6 months. However, the clinical

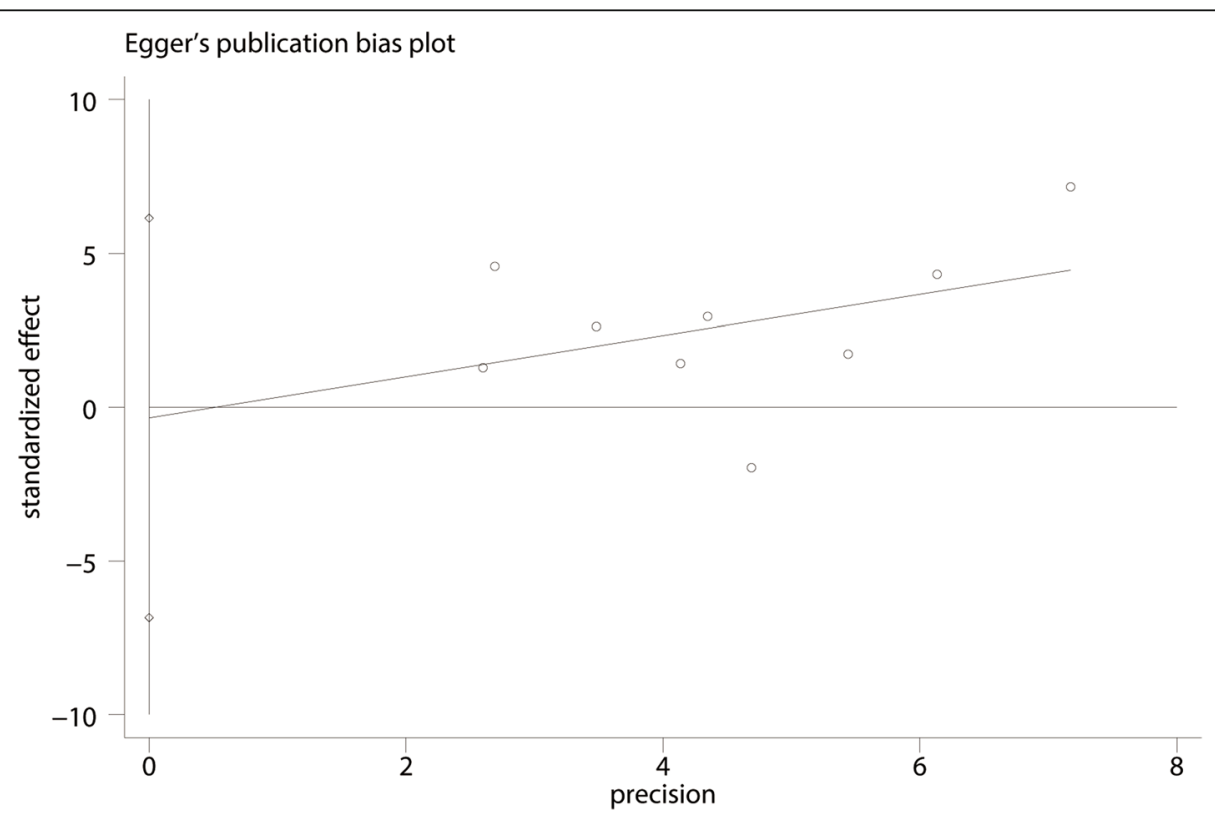

Fig. 11 Egger's test for overall function between the balance training group and control group 


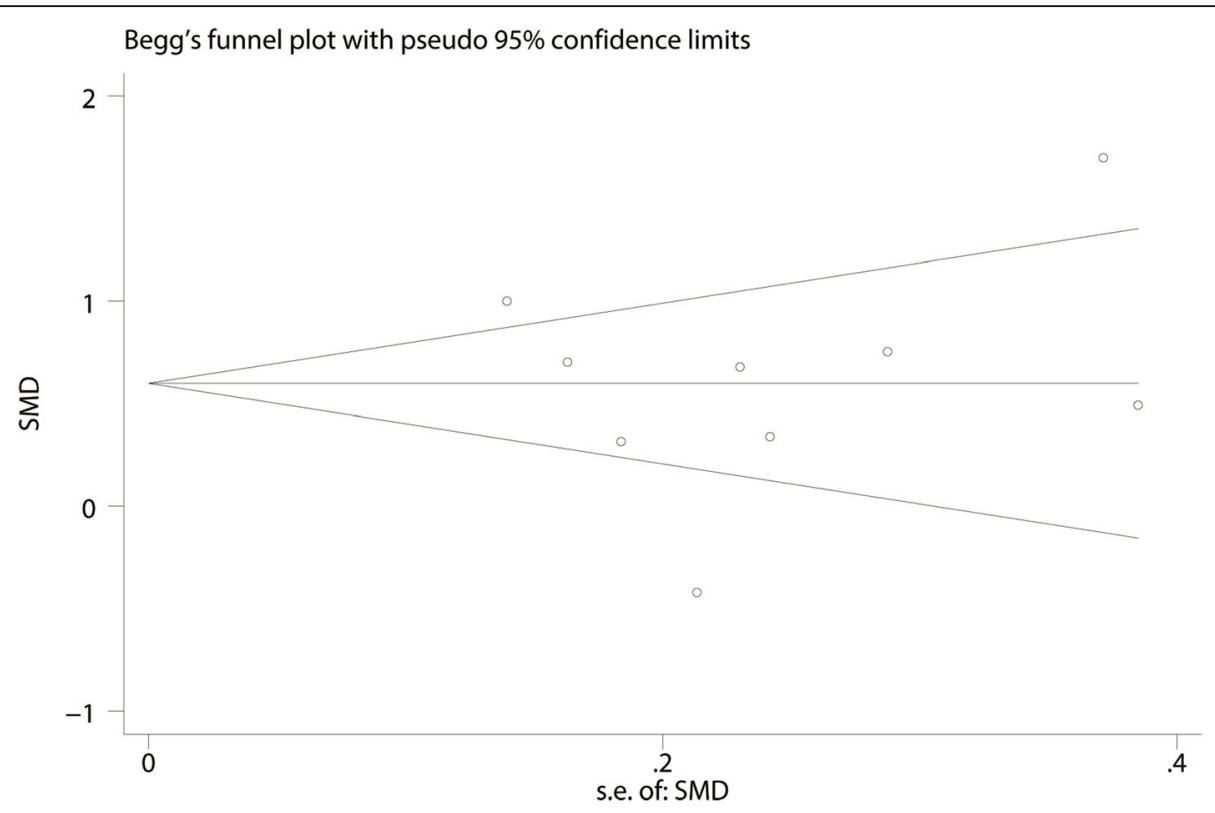

Fig. 12 Begg's test for overall function between the balance training group and control group

importance of the balance training remains to be determined.

Previous studies have shown that people have poor functional outcomes after hip fractures [23]. Following fracture, patients are at a high risk of entering a vicious cycle like fear of falling as well as post-fracture pain and muscle weakness [24]. Previous exercise studies using intensive professional supervision and equipment have found a significant capacity for adults with hip fracture to improve after balance training $[12,25]$. We included nine RCTs and found that balance training has a positive role in improving overall function, gait speed, and lower limb strength. ADLs were compared between the balance training and control group. Balance training is superior than the control group in terms of the ADLs. Moreover, balance training in the balance training group increased HRQoL scores than in the control group. Combs et

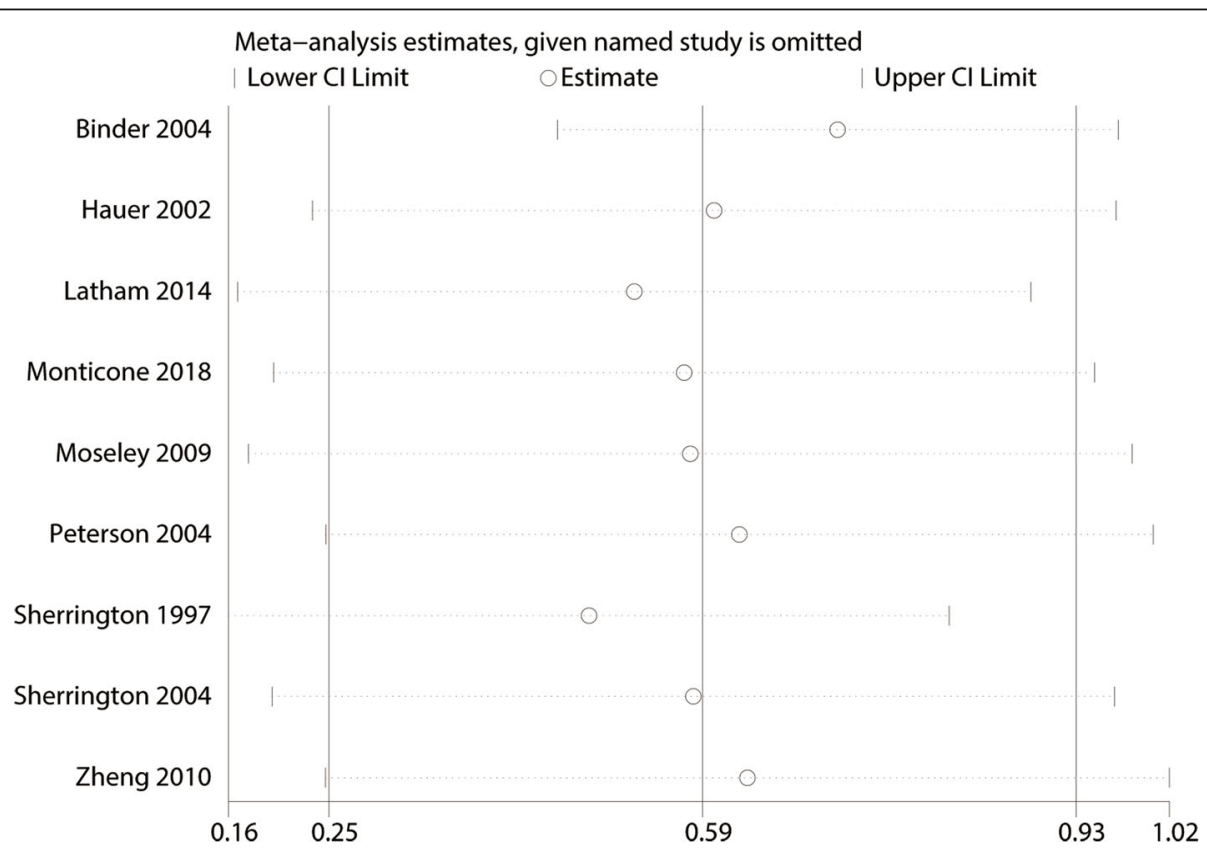

Fig. 13 Sensitivity analysis for overall function between the balance training group and control group 
Table 2 Subgroup analysis results

\begin{tabular}{|c|c|c|c|c|c|}
\hline Subgroup & No. of trials & Standard mean difference $(95 \% \mathrm{Cl})$ & $P$ value & $P^{2}(\%)$ & Test of interaction, $P$ \\
\hline Total & 9 & $0.59(0.25,0.93)$ & 0.001 & 81.9 & \\
\hline \multicolumn{6}{|l|}{ Training duration } \\
\hline$\leq 3$ months & 3 & $0.71(0.41,1.01)$ & 0.000 & 69.3 & \multirow[t]{2}{*}{0.106} \\
\hline$>3$ months & 3 & $0.57(0.41,0.72)$ & 0.000 & 88.2 & \\
\hline \multicolumn{6}{|l|}{ Risk of bias } \\
\hline Low & 3 & $0.70(0.47,0.94)$ & 0.000 & 0.0 & \multirow[t]{2}{*}{0.028} \\
\hline Unclear/high & 3 & $0.54(0.38,0.71)$ & 0.000 & 88.4 & \\
\hline \multicolumn{6}{|c|}{ Frequency of training } \\
\hline$\leq 3$ days a week & 7 & $0.52(0.37,0.68)$ & 0.000 & 82.4 & \multirow[t]{2}{*}{0.002} \\
\hline$>3$ days a week & 2 & $0.86(0.57,1.16)$ & 0.000 & 83.5 & \\
\hline \multicolumn{6}{|l|}{ Follow-up } \\
\hline$<6$ months & 5 & $0.78(0.54,1.01)$ & 0.000 & 57.8 & \multirow[t]{2}{*}{0.105} \\
\hline$\geq 6$ months & 1 & $0.50(0.33,0.67)$ & 0.000 & 88.1 & \\
\hline
\end{tabular}

al. [26] revealed that balance training could significantly increase health-related quality of life.

Overall, there were several strengths in our research which are as follows: (1) comprehensive retrieval strategy was applied to reduce the risk of publication bias, and (2) we performed sensitivity analysis and subgroup analysis to further increase the robustness of our final results.

Nevertheless, our meta-analysis does have certain limitations which needed to be addressed: (1) training frequency, duration, and follow-up were different, and thus, there is a large heterogeneity for the final outcomes; (2) follow-up duration was relatively short to assess the clinical effects of balance training; thus, long-term effects of balance training was needed; and (3) the detailed blind methods and allocation concealment were not described in some RCTs that may affect the validity of the overall findings.

\section{Conclusion}

Our meta-analysis revealed that the balance training group has improved overall physical functioning, gait, lower limb strength, performance task, and activity of daily living than the control group. More high-quality and large-scale RCTs are needed to identify optimal regimen of balance training after hip fracture.

\section{Abbreviations \\ ADLs: Activities of daily living; Cl: Confidence interval; HRQoL: Health-related quality of life; PRISMA: Preferred Reporting Items for Systematic Reviews and Meta-Analyses; RCTs: Randomized controlled trials; SMD: Standard mean difference}

\section{Acknowledgements}

None.

\section{Funding}

There is no funding for this article.
Availability of data and materials

We state that the data will not be shared since all the raw data are present in the figures included in the article.

Authors' contributions

JQW and LBM conceived the study design. JW performed the study, collected the data, and contributed to the study design. LBM and JW prepared the manuscript. JW edited the manuscript. All authors read and approved the final manuscript.

Ethics approval and consent to participate

Not applicable.

Consent for publication

Not applicable

Competing interests

The authors declare that they have no competing interests.

\section{Publisher's Note}

Springer Nature remains neutral with regard to jurisdictional claims in published maps and institutional affiliations.

\section{Author details}

${ }^{1}$ Rehabilitation Department, Jingjiang People's Hospital, Jingjiang, Taizhou, Jiangsu Province, China. ${ }^{2}$ Institute Office, Jingjiang People's Hospital, No. 28 Zhongzhou road, Jingjiang, Taizhou 214500, Jiangsu Province, China.

Received: 16 December 2018 Accepted: 11 March 2019

Published online: 20 March 2019

\section{References}

1. van Ooijen MW, Roerdink M, Trekop M, Janssen TW, Beek PJ. The efficacy of treadmill training with and without projected visual context for improving walking ability and reducing fall incidence and fear of falling in older adults with fall-related hip fracture: a randomized controlled trial. BMC Geriatr. 2016;16(1):215.

2. Kronborg L, Bandholm T, Palm H, Kehlet H, Kristensen MT. Effectiveness of acute in-hospital physiotherapy with knee-extension strength training in reducing strength deficits in patients with a hip fracture: a randomised controlled trial. PLoS One. 2017;12(6):e0179867.

3. McKenzie Al, Briggs RA, Barrows KM, Nelson DS, Kwon OS, Hopkins PN, Higgins TF, Marcus RL, Drummond MJ. A pilot study examining the impact of exercise training on skeletal muscle genes related to the TLR signaling 
pathway in older adults following hip fracture recovery. J Appl Physio (1985). 2017;122(1):68-75

4. Briggs RA, Houck JR, LaStayo PC, Fritz JM, Drummond MJ, Marcus RL. Highintensity multimodal resistance training improves muscle function, symmetry during a sit-to-stand task, and physical function following hip fracture. J Nutr Health Aging. 2018:22(3):431-8.

5. Chan DC, Chang CB, Han DS, Hong CH, Hwang JS, Tsai KS, Yang RS. Effects of exercise improves muscle strength and fat mass in patients with high fracture risk: a randomized control trial. J Formos Med Assoc- Taiwan yi zhi. 2018;117(7):572-82.

6. Lee SY, Yoon BH, Beom J, Ha YC, Lim JY. Effect of lower-limb progressive resistance exercise after hip fracture surgery: a systematic review and metaanalysis of randomized controlled studies. J Am Med Dir Assoc. 2017;18(12): 1096.e1019-26.

7. Heiberg KE, Bruun-Olsen V, Bergland A. The effects of habitual functional training on physical functioning in patients after hip fracture: the protocol of the HIPFRAC study. BMC Geriatr. 2017:17(1):23.

8. Resnick B, Beaupre L, McGilton KS, Galik E, Liu W, Neuman MD, GruberBaldini AL, Orwig D, Magaziner J. Rehabilitation interventions for older individuals with cognitive impairment post-hip fracture: a systematic review. J Am Med Dir Assoc. 2016:17(3):200-5.

9. Lima CA, Sherrington C, Guaraldo A, Moraes SA, Varanda RD, Melo JA, Kojima KE, Perracini M. Effectiveness of a physical exercise intervention program in improving functional mobility in older adults after hip fracture in later stage rehabilitation: protocol of a randomized clinical trial (REATIVE Study). BMC Geriat. 2016;16(1):198.

10. Shamseer L, Moher D, Clarke M, Ghersi D, Liberati A, Petticrew M, Shekelle P, Stewart LA. Preferred reporting items for systematic review and metaanalysis protocols (PRISMA-P) 2015: elaboration and explanation. BMJ (Clinical research ed). 2015;350:g7647.

11. Higgins JPT, Green S: Cochrane handbook for systematic reviews of interventions,version 5,1.0,updated Mar 2011. https://www.cochranehandbookorg/2012, 2012.

12. Binder EF, Brown M, Sinacore DR, Steger-May K, Yarasheski KE, Schechtman KB. Effects of extended outpatient rehabilitation after hip fracture: a randomized controlled trial. Jama. 2004:292(7):837-46.

13. Hauer K, Specht N, Schuler M, Bartsch P, Oster P. Intensive physical training in geriatric patients after severe falls and hip surgery. Age Ageing. 2002; 31(1):49-57.

14. Latham NK, Harris BA, Bean JF, Heeren T, Goodyear C, Zawacki S, Heislein DM, Mustafa J, Pardasaney P, Giorgetti M, et al. Effect of a home-based exercise program on functional recovery following rehabilitation after hip fracture: a randomized clinical trial. Jama. 2014; 311(7):700-8.

15. Monticone M, Ambrosini E, Brunati R, Capone A, Pagliari G, Secci C, Zatti G Ferrante $\mathrm{S}$. How balance task-specific training contributes to improving physical function in older subjects undergoing rehabilitation following hip fracture: a randomized controlled trial. Clin Rehabil. 2018;32(3):340-51.

16. Moseley AM, Sherrington C, Lord SR, Barraclough E, St George RJ, Cameron ID. Mobility training after hip fracture: a randomised controlled trial. Age Ageing. 2009;38(1):74-80

17. Peterson M, Ganz S, Allegrante J, Cornell C: High-intensity exercise training following hip fracture, vol. 20; 2004

18. Sherrington C, Lord SR. Home exercise to improve strength and walking velocity after hip fracture: a randomized controlled trial. Arch Phys Med Rehabil. 1997;78(2):208-12.

19. Sherrington $C$, Lord SR, Herbert RD. A randomized controlled trial of weight-bearing versus non-weight-bearing exercise for improving physical ability after usual care for hip fracture. Arch Phys Med Rehabil. 2004;85(5):710-6.

20. $X R Z, H W X Z, L P L$. Effects of visual feedback balance training with MTD balance assessment and training system on the equilibrium function and the mobility function in hip fracture patients. Chin J Rehabil. 2010;25(3):197-9.

21. Lee SY, Jung SH, Lee SU, Ha YC, Lim JY. Effect of balance training after hip fracture surgery: a systematic review and meta-analysis of randomized controlled studies. J Gerontol A Biol Sci Med Sci. 2018. [Epub ahead of print]

22. Doma K, Grant A, Morris J. The effects of balance training on balance performance and functional outcome measures following total knee arthroplasty: a systematic review and meta-analysis. Sports Med. 2018; 48(10):2367-85.
23. Auais M, Morin S, Finch L, Ahmad S, Mayo N. A prospective 1-year study of care process and functional recovery following osteoporotic hip fractures. Osteoporosis International. 2012;23(suppl 2):5.

24. Nilsson M, Eriksson J, Larsson B, Oden A, Johansson H, Lorentzon M. Fall risk assessment predicts fall-related injury, hip fracture, and head injury in older adults. J Am Geriatr Soc. 2016;64(11):2242-50.

25. Auais MA, Eilayyan O, Mayo NE. Extended exercise rehabilitation after hip fracture improves patients' physical function: a systematic review and metaanalysis. Phys Ther. 2012;92(11):1437-51.

26. Combs SA, Dugan EL, Passmore M, Riesner C, Whipker D, Yingling E, Curtis AB. Balance, balance confidence, and health-related quality of life in persons with chronic stroke after body weight-supported treadmill training. Arch Phys Med Rehabil. 2010;91(12):1914-9.

\section{Ready to submit your research? Choose BMC and benefit from:}

- fast, convenient online submission

- thorough peer review by experienced researchers in your field

- rapid publication on acceptance

- support for research data, including large and complex data types

- gold Open Access which fosters wider collaboration and increased citations

- maximum visibility for your research: over $100 \mathrm{M}$ website views per year

At BMC, research is always in progress.

Learn more biomedcentral.com/submissions 